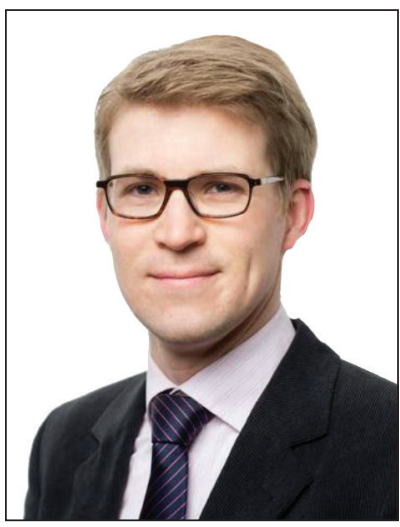

Hoffmann Thomas,

PhD, associate professor,

School of Law, Tallinn Technology University

e-mail: thomas.hoffmann@ttu.ee

doi: 10.21564/2414-990x.138.105313

UDC 341.9

\title{
EUROPEANISATION OF PRIVATE LAW IN UKRAINE. COMPARISONS IN THE FIELD OF LAW OF OBLIGATIONS
}

The fate of the EU-Ukraine Association Agreement - although finally signed between March and June 2014 - shows in a nutshell the nature of the more than 20 years of approximation between the European Union and Ukraine: A series of ambitious leaps towards the west, but few of them strong enough to not to be pulled back by the lack of respective legal implementation, legal reforms and - last not least - the lack of will. Much has been written about the weal and woe of Ukraine's Europeanization, and literature will even increase after the ongoing escalations of this year will hopefully have ended soon. Still, less has been written about what has been achieved already in terms of legal harmonization, especially in a field much less touched by politics, as it is the law of obligations - in spite of an obvious need for both academics and practitioners. This article therefore provides a comparison of the Ukrainian law of obligations with European harmonization initiatives - here represented by the Draft Common Frame of Reference (DCFR) - and aims at pointing out these fields of law, where further approximation could be obtained.

Keywords: europeanisation; private law; harmonization; law of obligations.

Хоффман Томас, доктор философии (PhD), доцент, Школа права Таллиннского технологического университета, Эстония, г. Таллинн.

e-mail: thomas.hoffmann@ttu.ee

Европеизация частного права в Украине. Сравнительный анализ в области обязательственного права

Судьба Соглашения об ассощиащии между Европейским Союзом и Украиной, подписанного в марте-июне 2014 г., демонстрирует характер более чем 20-летнего процесса сближения ЕС и Украинь: серия амбициозных прыжков на запад, немногие из которых были достаточно сильны, чтобы в полной мере соответствовать юридической реализащии правовых реформ, и, что не менее важно, - отсутствие политической воли. Много было написано о плюсах и минусах европеизаиии Украины, и такие публикащии будут появляться все чаще после того, как продолжающаяся ныне әскалация наконеи, закончится. Но немного написано о том, что уже достигнуто с точки 
зрения юридической гармонизащии, особенно в области, гораздо менее затронутой политикой, сфере обязательственного права. Поэтому в данной статье проводится сравнение украинского законодательства об обязательствах с европейскими инициативами гармонизации: представлен проект общей системы отсчета (DCFR), цель которого - указать области права, где возможно дальнейшее сближение.

Ключевые слова: европеизация; частное право; гармонизация; обязательственное право.

Introduction. Ukraine's 1996 Constitution declared the State to be "democratic, social, and law-based", shaping a framework which since then has been implemented into practice only to certain degrees, as far as the strict enforcement of the rule of law is concerned. Still, approximation with the European Union also in the field of law has since then been an explicit goal of various Ukrainian governments. The envisaged "Europeanization" in terms of human rights protection, anti-corruption measures or the establishment of a comprehensive welfare system experienced a considerable drawback in November 2013, when the partnership and trade agreement ${ }^{1}$ with the EU was repelled at the Eastern Partnership Summit in Vilnius, setting the approximation procedure into a state of "hibernation" even before the annexation of the Crimea by the Russian federation and subsequent military operations in Eastern Ukraine.

Against this background, the goal of this paper is less to analyse the different steps and procedures of approximation taken within the last decade - as already provided in detail e.g. by Petrov ${ }^{2}$ last year -, nor is it to speculate about the future development of these once successfully initiated measures. This paper simply aims at analysing and comparing what the contents of substantial Ukrainian private law especially its law of obligations - is actually about. The paper focusses here less on dogmatic reflections - see for this e.g. recently Luts on Law of Contracts ${ }^{3}-$, but rather on the text of the positive law itself, in this case the Ukrainian Civil Code and, partly, the Ukrainian Commercial Code. Following a general systematization of Ukrainian private law within the framework of other continental European civil law systems, this task will be performed by the comparative analysis of ten standard situations between private law and Western European systems. These are here since the proposal Common European Sales law has unfortunately been withdrawn earlier this year ${ }^{4}$-represented by the Draft Common Frame of Reference (DCFR) ${ }^{5}$, which successfully serves as common denominator for various private law unification proposals not only after it was finally fully published in six volumes (containing comments and comparative notes) in October 2009. ${ }^{6}$ The DCFR was very positively

\footnotetext{
${ }^{1}$ See the resumй «A look at the EU-Ukraine Association Agreement», published on 27 April 2015 on the European Union External Action homepage.

2 Petrov, Roman, (2013), 173-185.

${ }^{3}$ Luts, V. (2012), 97-113.

${ }^{4}$ For background information see Clive, Eric, on „European Private Law News“, posted on January 7, 2015.

${ }^{5}$ The text of the DCFR is online accessible at http://ec.europa.eu/justice/policies/civil/docs/dcfr_ outline_edition_en.pdf.

${ }^{6}$ For a detailed overview on background and genesis of the DCFR see Antoniolli, Luisa; Fiorentini, Francesca (2010), 1-27.
} 
acclaimed not only in Europe ${ }^{1}$ and has - after some years of somewhat vague perspectives - now apparently reached a status of general recognition. ${ }^{2}$

\section{The System of Ukrainian Private Law.}

1. Special Features. Although Ukraine is a civil law culture, three aspects of the Ukrainian private law system challenge the average Western European law practitioner in a special way.

First of all, the Ukrainian law of obligations is marked by a dual structure ${ }^{3}$. Both the Civil Code of Ukraine (CCU, Цивільний кодекс України) as well as the Economic Code of Ukraine (ECU, Господарський кодекс України) regulate private law matters. Differentiation would be simple if application of the respective code followed clear conditions. However, as the ECU does not only refer to business entities, but to every kind of legal action in the "field of production (...) and sale of products" (art. $3 \mathrm{Nr}$. 1 ECU), principally almost all major every-day legal transactions can be subject to ECU application. This essential discrepancy does not only provide Ukrainian legal secondary literature a boasting field of exertion, but also causes serious difficulties in every-day legal practice, as both codes are not fully compatible with each other, ${ }^{4}$ and as especially the ECU is marked by a somewhat backward spirit. In fact, one of the most essential findings within a OECD-assessment undertaken on the Ukrainian legal system in 2004 was that the ECU has a "decided tendency towards re-establishing a command economy", for instance by "its empowerment of the government to dictate the actions of companies and to deprive companies of various benefits and privileges when they do not comply with government demands". ${ }^{5}$ The report's central advice was thus to abolish the ECU altogether, as its regulations rather disturb the functioning of the Ukrainian private law system than supplementing it effectively. ${ }^{6}$

Another characteristic element of both the CCU and the ECU is their additive structure. Although there is formally a "general part", the majority of legal consequences - as payment of losses, return of money, duty to perform in kind - is situated in the respective separate provision. Due to this fragmentary specialisation, a considerable number of cases cannot be solved completely in accord with the respective stattja.

Finally, the comparably short life expectancy of both CCU and ECU provisions (more than a dozen amendments in both codifications only within the last twelve months) provide a lasting challenge to both legal and business practitioners.

\footnotetext{
${ }^{1}$ For a non-European evaluation see Emmert, Frank, The Draft Common Frame of Reference (DCFR) - The Most Interesting Development in Contract Law Since the Code Civil and the BGB (2012).

${ }^{2}$ Even in the Common Law world, see e.g. the recent article by Richardson, Lorna (2014), The DCFR, Anyone?, in the "Journal of the Law society of Scotland".

${ }^{3}$ Biryukov, Alexander (2010), 53-78.

${ }^{4}$ OECD-report "Legal issues with regard to business operations and investment in Ukraine" (2004), $18-25$.

${ }^{5}$ OECD-report (2004), 8.

${ }^{6}$ OECD-report (2004), 9.
} 
2. Structure. The Ukrainian private law does not contain an abundance of laws. Of genuine civil law nature are only the following laws: The Civil Code of Ukraine ${ }^{2}$ in six books, containing General Provisions (parties and objects to legal relations, legal transactions, limitation of action), Personal non-property rights of a natural person, Ownership and other property rights, Intellectual property rights, Obligations, and Law of succession; a Family Code, an Economical Code ${ }^{3}$ and a Law on securities and stock exchange.

However, these laws are supported by a vast number of by-laws and supplementary provisions. As far as public matters are concerned, the density of regulations by law rises.

3. Methodology. This paper provides a mere general outset on Ukrainian law of obligations and therefore cannot give detailed advice on the crucial question whether generally the CCU or the ECU will be applied. As the formal subsidiarity of the $\mathrm{CCU}$ in practice is impeded in many cases, the question of application will have to be answered for each case basing on the specific circumstances. Anyway, the CCU will remain the main code used for the comparative solutions.

In general, this approach should be also followed in legal practice. However, if there is any element pointing towards application of the ECU, the following procedure should be applied:

1. Step: Section on separate types of contract in the ECU $\rightarrow$

2. Step: General provisions on obligation within the $E C U \rightarrow$

3. Step: General provisions of the $E C U \rightarrow$

4. Step: Section on separate types of contract in the $\mathrm{CCU} \rightarrow$

5. Step: General provisions on obligation within the $C C U \rightarrow$

6. Step: General provisions of the CCU

The fact that finally approximately $60 \%$ of all cases are solved under the rule of $\mathrm{CCU}$ is due to the fragmentary character of the ECU, whose regulation density is considerably disproportionate (and in its contents often conflicting with the CCU). In this analysis, all articles without mentioned provenience are those of the CCU.

\section{The Law of Obligations.}

1. Basic characteristics. The law of obligations regulates debtor-creditor relationships. The term "obligation" is defined in Art. 509, being a legal relation where one party (the debtor) is obliged to perform an action to the benefit of the other party or to abstain from a certain action, while the creditor has the right to claim the performance of this obligation from the debtor; a definition thus quite similar to DCFR III 1:102.

The content of an obligation can, to a large extent, be determined by contract. However, Art. 526 states that the obligation shall be properly performed not only

\footnotetext{
${ }^{1}$ Laws partly accessible (in Ukrainian language) in the Ukrainian State Gazette's website at http:// ovu.com.ua/.

${ }^{2}$ Online accessible (in Ukrainian language) at http://zakon1.rada.gov.ua/laws/show/435-15

${ }^{3}$ Online accessible (in Ukrainian language) at http://zakon2.rada.gov.ua/laws/show/436-15. English translation available at http://www.wipo.int/wipolex/en/text.jsp?file_id=182251.
} 
according to the conditions of the contract, but also following the requirements of the Civil Code and other acts of civil law. Obligations may arise by a legal transaction, e.g. by contract, but may also have the law as their immediate source. They must be based on the principles of good faith, sense and justice, Art. 509.

Ukrainian law distinguishes between General provisions (section I, chapter 47, Art. 508-654), separate types of obligations (section II, chapter. 54, art. 655-1143) and non-contractual obligations, chapter 78 art. 1144-1157. Quasi-contractual relationships as negotiorum gestio are not or hardly regulated in Ukrainian law; Ukrainian private law even lacks a general regulation for unjustified enrichment.

\section{Case 1}

A intends to buy a wardrobe. While inspecting several items exhibited in B's furniture shop, he is hit by a falling chandelier negligently fixed by B. Subsequent medical treatment requires ca. 1.000 UAH. On which base can A claim damages?

Solution: The institute of culpa in contrahendo is not known in Ukraine. C will only be liable to A on the grounds of tort. Tor is regulated in chapter 82, "indemnification”. Ukrainian law provides general provisions in $\S 1$ (art. 1166-1194) and distinguishes between damages inflicted by mutilation and other health injuries including death (§ 2, art. 1195-1208) and damages due to defects of commodities ( $§$ 3, art. 1209-1211).

According to art. 1166, a person inflicting property damage is liable for all damages resulting from the violating action. As $\mathrm{C}$ cannot prove that the damage was inflicted without negligence or intent, Art. $1166 \mathrm{Nr}$. 2, he will be fully liable for damages. Art. 1196 states, by the way, that damages for health injuries will be treated equal to damages for property violation if the violating person inflicted the damage under performance of his or her contractual obligations. Liability will in other words - be restricted if the tortfeasor has contractual relations with the aggrieved party.

Conclusion: According to Ukrainian law, $\mathrm{C}$ will have to pay damages only on the base of tort law, i.e. art. 1166.

Pre-contractual liability belongs to the "common core" of most continental European legal systems ${ }^{1}$ and has thus been implemented in DCFR as well in art. II 3:301 par. 3. Such general duties of good faith at the negotiating state are unknown to Ukrainian law. This lack is, however, not due to dogmatic reasons as it is in the Anglo-American Common law ${ }^{2}$, but rather a shortcoming resulting from the grinding impact of the soviet past on hitherto existing private law instruments in Ukrainian law.

2. Agreements. According to Art. $626 \mathrm{I}$, an agreement is defined as an "arrangement between two or more parties targeting at the establishment, change, or termination of civil rights and responsibilities". An agreement can be unilateral, i.e. without counter obligation, or bilateral, Art. 626 II, III. The ECU provides respective provisions in art. 179. An agreement is concluded as soon as one party's proposal

\footnotetext{
${ }^{1}$ See for details Cartwright, John; Hesselink, Martijn W. (2010), 1-17.

${ }^{2}$ See for details Banakas, Stathis (2009), 1-21.
} 
to conclude an agreement is accepted by the other party to that extent that the parties reached a consensus on all essential provisions, Art. 638 II, 640 I (exceptions concerning the moment of conclusion in Art. 640 II, III).

The provisions on transactions base in many cases literally on the respective provisions on Rechtsgeschäfte of the German BGB. However, as the CCU regulates cancellation and amendment more precisely in the chapter on agreements, the practical importance of chapter 16 is not comparable to BGB book I, Title 2.

The offer as well as the acceptance must be received by the other person in order to have legal effect. Once the offer has been received, it is binding on the offeror. The offer only ceases to be valid if the other party does not accept within an eventually specified term of response, Art. 631 I, $643 \mathrm{ff}$.

\section{Case 2}

A offers to B a car at a price of $12.000 \mathrm{UAH}$ for sale via mail on Monday. On Tuesday, A changes his mind and writes another letter to B stating that he would not be ready to sell the car any more. On Wednesday, B receives A's first mail, agrees in writing and posts his letter at the post office. On Thursday, he receives A's second letter; A receives B's accepting letter on Friday. Is there any binding contract between $\mathrm{A}$ and $\mathrm{B} / \mathrm{C}$ ?

Solution: No. According to art. 642 par. 3, no binding contract is formed before the acceptance actually reaches the offeror. It is generally revocable before that time.

Ukrainian law follows here the path of continental European legal systems. Parallel to the DCFR, which states in Article II 2:402 par 1 that "an offer may be revoked if the revocation reaches the offeree before the offeree has dispatched an acceptance (...)", Ukrainian law regulates the issue distinctively against the Anglo-American Postal rule. ${ }^{1}$

3. Dissent. Dissent as such is not regulated by a separate provision. However, its legal consequence, the lack of a binding contract, can be depicted from art. 638, which states that there will be no agreement unless both parties agreed about all essential terms of contract.

\section{Case 3}

A offers B $100 \mathrm{~kg}$ of "Varenyky" for sale. B, a foreigner, ignores the actual meaning of Varenyky (being a kind of dumplings) and thinks it to be jam (ukr. Варення $=$ jam). He orders $100 \mathrm{~kg}$. After depicting his error, he claims being mistaken. Is A bound by a contract?

Solution: Art. 638 states that there will be no binding contract before all essential terms are regulated: Object, Price and term (duration of contract). Under this definition, no agreement has been concluded yet upon the object to be transferred. Therefore, there are no contractual obligations.

The DCFR defines an agreement in II 4:103 par 1 as follows: (1) Agreement is sufficient if: (a) the terms of the contract have been sufficiently defined by the parties for the contract to be given effect; or (b) the terms of the contract, or the rights

${ }^{1}$ For a comparison of the rule with the DCFR see Macdonald, Elisabth, (2013), at „3. The Revocation Issue“. 
and obligations of the parties under it, can be otherwise sufficiently determined for the contract to be given effect. The situation presented above would be - just as in e.g. German law - rather seen as a classical avoidance constellation.

In Ukrainian law, these approaches are not congruent. Art. 638 has a much broader scope of application than dissent-regulations in other continental European systems and is there of upmost importance in Ukrainian civil law practice: Whenever one of these essential elements is not specified in the contract, any of the party may claim its invalidity, however detailed the remaining part of the contract may be designed. The reason for this action would not be the mistake of one party, but an - obviously - deficient determination of the essentialia negotii. In consequence, dissent as regulated in art 638 - in western law a rather theoretical institute - is partly replacing classical continental European avoidance institutes and thus a commonly used legal tool in Ukraine.

4. Form. The agreement is generally formless, Art. 205, 639 I. However, in some special cases certain forms must be complied with, see art. 206-213.

Non-compliance with these and other requirements may lead to legal consequences provided in $\S 2$, art. 215-235. If the non-compliance results in invalidity, the transaction will be considered as invalid from the moment of conclusion (ex tunc), art. 236.

\section{Case 4}

A signs a business lease contract with $\mathrm{B}$. They agree about a leasing term of five years, but B ignores contract notarisation. Nevertheless, A moves in and duly pays the lease agreed upon. After two years, B intends to lease the premises to another person. He summons A to leave the premise, as the contract was void due to the lack of notarisation / registration. Is A obliged to leave?

Solution: According to art. 793 II, a lease contract for a term more than years has to be notarized. If this form is not met, the contract generally will be void, art. $219 \mathrm{I}$.

However, according to 219 II, the court may declare a generally invalid transaction valid if the notarization was hindered by a circumstance which was beyond control of the person claiming validity. In the present case, there are good chances for A, as the duty to notarization was carried by B.

While II 2 1:106 DCFR states plainly in its first par. that "a contract or other juridical act need not be concluded, made or evidenced in writing nor is it subject to any other requirement as to form," Ukrainian law assigns major importance to form. Quite often invalidity will not be an automatic legal consequence if certain conditions are not met, but the party may claim the contract's invalidity in order to let it be declared void by the court. The same applies vice versa, if a void contract is claimed to be valid on base of bona fide. Provisions as sec. 518 par 2, 311b BGB which may lead to irrelevance of the defective form by execution are not explicitly provided by Ukrainian law nor used in an equivalent function by courts applying the Ukrainian civil code.

\section{Special types of agreements.}

5.1. Adhesion contracts. The regulation concerning "adhesion contracts", art. 634, refer to standard form contracts (see respective definition in par. 1). 


\section{Case 5}

A concludes a purchase contract between him and buyer B in form of an adhesion contract (i.e. standard business terms). One of the adhesion contract's provisions state that A will not be liable even for intentional contract violation. After conclusion B changes his mind and refuses to be bound by the contract. Is B bound nevertheless?

Solution: A standard form contract may be substituted or terminated upon the demand of the joining party, if the agreement excludes or restricts the responsibility of the offeror for violating his or her obligation or contains other provisions obviously burdensome for the joining party. However, the joining party has to proof that respective provisions deprive his or her usual rights "clearly", Art. 634 II. Such a proof will presently easily be obtained, since art. 614 states that a transaction terminating the responsibility for deliberate violation will be void. A can successfully demand the adhesion agreement to be terminated, as far as the restriction of liability is concerned. The remaining parts of the adhesion agreements are not concerned and remain binding, art. 217.

In spite of being a mere "common frame", the DCFR regulates in detail business terms, providing not only general definitions for terms "not individually negotiated" (see II 1:109), but catalogues for "significantly disadvantaging terms" (II 9:403) as well, see II 9:410. In spite of its purpose as comprehensive codification, the Ukrainian code is here much shorter; it simply states that all terms "явно обтяжливі для сторони" (clearly disadvantaging the other party) provide a claim to terminate the contract to the aggrieved party.

6. Representation. Representation can be based on contract, the written law, the act of a body of a legal entity or on other grounds established by acts of civil legislation, Art. 237 III.

\section{Case 6}

A, living in Kyiv, intends to purchase a car from B in Odessa. He asks his companion $\mathrm{C}$ to act on behalf of himself, as $\mathrm{C}$ lives in Bessarabia himself. For this purpose $\mathrm{C}$ is supplied with a power of attorney, duly signed by A and restricted to the current month. According to the power of attorney, $\mathrm{C}$ is authorized to transfer authorization to third persons. On his way to $\mathrm{B}, \mathrm{C}$ gets hurt in a car accident. C calls his friend $\mathrm{D}$ and tells him to conclude the purchase contract, but he does not (nor does D) inform A about it. Hereafter D signs the contract in the name of A with B.

Two days later A regrets his decision and decides to purchase another car. He states that he was not bound by any contract, as he did not authorize D to represent him.

Can B demand payment of the purchase price? If so, who has to pay?

Solution: Generally - according to art. 240 - the transfer of authorization is possible, as far as it is provided by the contract or the law.

In the present case such a provision is envisaged by the power of attorney. The power of attorney is valid, as it complies with terms of expiration (if he failed to do so, the power of attorney were void, Art. 247 III). However, art. 240 II states that 
the representative is obliged to inform the represented party about the transfer and about the person to whom the power of attorney/authorization was transferred. If he fails to do so, the representative will be bound for the obligation himself.

Therefore $\mathrm{C}$ became party to a binding contract and has to pay the purchase price himself.

\section{Modification I:}

C purchases two cars for A. A refuses to pay for both cars, as he did not order $\mathrm{C}$ to buy a second car. Does A have to pay both cars?

Solution: No. C has to pay for both cars. Art. 241 states that the agreement creates rights and obligations only upon approval of the represented person. If a contract concluded by the representative beyond authority is not approved, the representative will be bound himself.

\section{Modification II:}

When C left hospital after a few days (but still in the current month), he forgot to conclude the envisaged contract with $\mathrm{B}$. In consequence, B sold the car to another person. A had to purchase an equivalent car for a higher price from E. Can A demand payment of the losses from C?

Solution: Generally, the representative can refuse to perform actions assigned by a power of attorney, art. 250. However, he has to inform immediately the represented person, art. 250 II. If he fails to do so, he will be liable for the losses, art. 250 IV.

Ukrainian law regulates representation in the first book (general provisions) of the Civil Code, chapter 17 art. 237-250. There are no prevailing provisions in the section about separate types of obligations neither in the economic code (for example, the economic code does not mention commercial forms of representation; art. 243 is exhaustive for commercial representation as well). Nevertheless, these "commercial representatives" do not equal the "procurator" of German / Austrian law; they can be stockbrokers or securities traders, i.e. exclusively fulfil functions in financial matters.

The representative may conclude any transaction the represented person can conclude him/herself, as long as the represented person has not to conclude personally. As far as a representative exceeds his authority, the transaction will only bind the represented person after his or her approval, art. 241.

While in Western European civil law systems generally the "principal's authorisation may be granted express or impliedly" (DCFR II 6:103 par 2), it is of major importance in Ukrainian law that powers of attorney (in Ukrainian Довіреність) are not only issued in written form, but in general even notarized (art. 245 par. 1 and 2) and regulated respectively broadly, see art. 244-250, leading in practice to difficulties of the same kind as referred to in case 4.

6. Violations of Obligations. According to art. 610, violation of the obligation can be its non-performance or any form of performance violating the provisions determined by the content of the obligation (undue execution).

Ukrainian law does not provide any regulations directly referring to secondary duty violation. The agreement has to be interpreted in order to use the contract 
itself as a legal basis for damages claims. Courts may also be flexible concerning the recognition of the respective contract passages, as the violation of secondary duties is a major issue in legal practice and tort law does not provide sufficient grounds for compensation in all cases.

\section{Case 7}

Carrier $\mathrm{C}$ transports furniture into the apartment of client $\mathrm{A}$. As $\mathrm{C}$ passes the apartment's doorway, he negligently demolishes the wallpaper at a length of $0.5 \mathrm{~m}$. The existing hauling contract between $\mathrm{C}$ and $\mathrm{A}$ does not provide any provisions about this kind of damage.

On which legal base can A claim damages?

Solution: Possibly C violated the contract with A. According to the contract, C had to transport furniture from another place to A's apartment. However, the contract does not explicitly refer to damages occurred during the work. Nevertheless, there could be legal grounds for damages on contractual base.

Ukrainian law does not provide positive regulations about the consequences of secondary duties' violation. But as mentioned above, $\mathrm{C}$ could be liable to A on the grounds of tort. According to art. 1166, a person inflicting property damage is liable for all damages resulting from the violating action. As $\mathrm{C}$ cannot prove that the damage was inflicted without negligence or intent, art. $1166 \mathrm{Nr}$. 2, he will be fully liable for damages.

Conclusion: According to Ukrainian law, $\mathrm{C}$ will have to pay damages only on the base of tort law, i.e. art. 1166.

Ukrainian law did not implement liability for the violation of secondary duties (as known in German law in sec. 241 II BGB) and is in this point similar to the approach of the DCFR, which also does not provide any claims for the violation of "Nebenpflichten", as far as they were not explicitly determined in the contract. ${ }^{1}$ Just as in the DCFR, claims are restricted to tort, which in Ukrainian law is regulated in chapter 82, "indemnification". Ukrainian law provides general provisions in $\S 1$ (art. 1166-1194) and distinguishes between damages inflicted by mutilation and other health injuries including death (§2, art. 1195-1208) and damages due to defects of commodities (§ 3, art. 1209-1211).

Losses are determined by taking into account the market prices existing at the day of voluntary satisfaction of the creditor's claim by the debtor at the place of performance, respectively - if the claim was not voluntarily performed - at the day of bringing up the claim, art. 623 par. 3 .

7. Responsibility. According to art. $614 \mathrm{ff}$, responsibility is generally fault-based (intent, gross negligence or simple negligence).

\section{Case 8}

A lets is hair dressed by B. During performance, B cuts off the major part of A's hairstyle due to a sudden and intense earthquake. Will B be liable for damages, as A calls for a toupee?

\footnotetext{
${ }^{1}$ Kieninger, Eva-Maria (2012), 218.
} 
Solution: According to Art. 614 I, a violator will only be liable as far his guilt (intent or negligence) is obvious. Does he or she prove that he or she made use of every possible means to perform properly, he or she will not be deemed responsible. A violator shall also be released from responsibility if he or she proves that the violation was due to a contingency or to force majeure, Art. 617 I. Still, responsibility for negligent (i.e. non-deliberate) violation can be restricted or terminated by legal agreement.

Anyhow, the creditor carries the burden of proof for the existence and extent of the losses, Art. 623. A has to prove that his present haircut is a damage eligible for compensation.

Ukrainian law follows here the doctrine of fault-based liability, providing exculpation mechanisms quite similar to those of German law. In consequence, it partly contradicts the general rule of strict liability as implemented in the DCFR III 3:104, providing "force majeure" and - concerning the amount of damages - foreseeability (DCFR III 3:703) as sole elements restricting the debtor's liability. ${ }^{1}$

8. Termination of Obligations. Chapter 50 provides eight ways which lead to termination of an obligation: Performance, art. 599; transfer of indemnity, art. 600; offset, art. 601; parties' consent, art. 604; remission of debt, art. 605; union of debtor and creditor in one person, art. 606; impossibility, art. 607; respectively death of the debtor, art. 608 / Liquidation of legal entity, art. 609.

Together with rescission, art. 615, in practice performance, offset and impossibility are the most important ways of termination.

1. Termination by performance: Place of performance

The proper performance in terms of art. 526 leads to termination of obligation, art. 599.

As far as the contract does not specify a place of performance, it will be determined from the circumstances of the legal relationship, Art. 532 Nr.1-5; otherwise, the place for performance will be the debtor's residence, Art. $532 \mathrm{Nr}$. 5. However, special conditions can be provided by separate types of obligations and by the ECU.

\section{Case 9}

A orders a wardrobe from $\mathrm{B}$ and pays in advance. B produces the wardrobe and - as A and B agreed - delivers it to A. During transport, the wardrobe gets damaged.

Is A entitled to the delivery of a defect-free wardrobe?

Solution: According to art 526, B had to perform properly according to the contract. B had to produce a wardrobe within time and free of any defects. Before delivery, such a wardrobe existed. However, performance has to take place on the right place as well.

The general provisions (here art. 532 par. 3) state for obligations on transfer of commodities (property) the place of production to be the right place. A would have properly performed.

${ }^{1}$ See also Eva-Maria Kieninger (2012), 209. 
However, purchase law provides a different regulation in art. $664 \mathrm{I}$ Nr. 1: If the goods are to be delivered to the buyer, the seller will not have performed before complete delivery. At that point of time, the wardrobe was already defective. B did not perform.

\section{Modification:}

$\mathrm{B}$ produces the wardrobe, but does not perform. On which legal base can A claim performance?

Solution: Generally, the contract itself provides a sufficient legal base for claiming transfer of property. However, art. 620 states that the creditor shall have the right to claim this object from the debtor and its transfer, if the debtor does not perform his obligation to transfer an object specified by individual characteristics to the creditor's possession. As the wardrobe has not already been assigned into a third person's possession, Art. 620, A can base his claim against B on art. 620 as well.

Art. 197 ECU provides further amendments of these principles of place of performance (e.g. for land plots, constructions, monetary obligations).

If for performance no time period (term) is established in the agreement, the creditor has the right to claim performance at any time, art. 530 II. The debtor has in that case to perform this obligation within a period of seven days since the day of bringing up the claim.

The term time period can refer to the point of time when the debtor may perform (if performance is not accepted by the creditor, he may be liable according to art. 612) or when the debtor has to perform (violation of this obligation may lead to consequences according to art. 613).

The place of performance - especially of subsequent performance - has been in the focus of various practical and academic discussions in the European legal space lately. ${ }^{1}$ In Ukrainian law, the respective regulations is, anyway, rather short, basically running parallel to DCFR III 2:101, where the place of performance is - in case of doubt - the seller's residence. If the goods were sent to the buyer - as in our case - the risk passes in the DCFR, anyway, already when the goods are passed to the delivery person, IV A :202. Ukrainian law differs in this point considerably not only from the DCFR, but also German law (447 BGB), stating that risk does also in this case not pass before the buyer in fact receives the good (вручення товару покупцеві).

2. Termination by Performance: Performance by cheque

Payment via cheque is one of the less often used performance types in Ukraine. The legal structure of cheque payment does not differ from Western European procedures.

\section{Case 10}

A opens a new branch of a café-chain in Kyiv. He decides to use cheques as general payment practice. How should he legally be advised in order to avoid difficulties?

1 On the place for subsequent performance see e.g. recently Hoffmann, Thomas (2014), 383-394. 
Solution: The CCU does not provide a clear legal structure which can be laid down as a base for cheque payment. Nor art. 528 (performance by third parties) neither the provisions about representations cover the character of cheque payment sufficiently. However, cheques are generally acknowledged as means of payment in practice, and several bylaws regulate cheque payment.

In the DCFR, III 2:108 mentions the "cheque" in par. 2 as a method of payment as well, but its significance in the European legal system the DCFR derives from is by far less than in the Ukraine, see the 74th chapter of the CCU, where $\S 5$ regulates settlements by clearing house cheques, art. 1102-1106. Although details are regulated quite extensively, the question against whom the check holder may sue in case of non-payment remains unclear, art. 1106. Further details are regulated by the National Bank's by-law on cheque payment.

Legally there is no special obstacle to be evaded or avoided. Difficulties are rather caused by administrational efforts; e.g. each cheque payment has to be listed in the accounting department. Besides, the majority of business partners prefer cash payment.

8.1. Amendment of agreements. Grounds to amend or cancel agreements vaguely differ from many central European legal systems. However, due to the multilayer structure of the CCU, agreements can be cancelled according to the General Provisions (art. 229-235), the provisions about obligations (art. $611 \mathrm{Nr} .2$ ), the provisions on agreements (651), and - if applicable - to the respective provisions of the ECU (art. 188).

Besides of an amendment or cancellation by the parties' consent, the agreement can be amended or cancelled by court decision on request of one of the parties, Art. 651 II, if the agreement has been significantly violated, i.e. when the inflicted losses of the other party exceed the bargain expected by agreement conclusion. The agreement can as well be terminated if one party unilaterally refuses to perform, Art. 651 III.

Conclusion. The large-scale reforms of Ukrainian private law of 2004 raised hope that legal security and efficiency of the Ukrainian system of private law would be enhanced. The analysis of ten "standard" private law situations under Ukrainian law shows, against the background of European private law systems as here represented by the DCFR, that there is on first sight a quite close similarity in the general dogmatic approach, structure and dimensions of the Ukrainian Civil Code. This does not surprise, as even the Soviet civil code was structurally derived from continental European law principles, of which - based on $19^{\text {th }}$ century Russian law - the main model was German law, as seen e.g. in the case of fault-based liability for non-performance. Still, many main characteristic elements of German law (as the liability for the violation of secondary contractual duties) have not been implemented into Ukrainian law, while most "classical" civil law principles as defying the Anglo-American postal rule or can be found in Ukrainian private law till this day. 
A second sight, nevertheless, reveals that numerous elements of the "common core" of European private law are not fully or not implemented at all - what, by the way, does not automatically justify a verdict in terms of quality; transferring e.g. the classical avoidance-constellation to the "realm of dissent" may not lead to less fair judgements as such. But many of these differences still can only be evaluated as shortcomings. These can be found in general consumer law (e.g. in the lacking catalogue for void standard business terms), but also on simple dogmatic misconceptions as the lacking differentiation for carriage contracts concerning the passing of risk. The practically probably most essential specialty of Ukrainian private law is its abundance of form requirements, many of them amounting to the notarial level. These requirements - just as the vast amount of regulations on cheque transactions - do not only slow down business transactions and opens the doors to corruption, but seriously also impede Ukraine's quest for digitizing its legal communication.

\section{References:}

1. Antoniolli, Luisa, Fiorentini, Francesca. (2010). Introduction, in: A Factual Assessment of the Draft Common Frame of Reference, Sellier 2010, pp. 1-27.

2. Banakas, Stathis. (2009). Liability for Contractual Negotiations in English Law: Looking for the Litmus Test, InDret 2009/1, pp. 1-21.

3. Byrne, Peter. (2010). "Moskal: Rotten to the Core", article in the daily newspaper "Kyiv Post" on March 26, 2010. URL: http://www.kyivpost.com/content/business/moskal-rotten-to-thecore-62565.html.

4. Biryukov, Alexander. (2010). The Doctrine of Dualism of Private Law in the Context of Recent Codifications of Civil Law: Ukrainian Perspectives. Annual Survey of International E Comparative Law: Vol. 8: Iss. 1, Art. 4, pp. 53-78.

5. Clive, Eric. (2015). Proposal for a common European sales law withdrawn. European Private Law News, posted on January 7, 2015. URL: http://www.epln.law.ed.ac.uk/2015/01/07/proposal-for-a-common-european-sales-law-withdrawn/.

6. Directorate for Financial and Enterprise Affairs of the OECD. (2004). Report "Legal issues with regard to business operations and investment in Ukraine", published in October 2004. URL: http://www.oecd.org/countries/ukraine/34514482.pdf.

7. Emmert, Frank. (2012). The Draft Common Frame of Reference (DCFR) - The Most Interesting Development in Contract Law Since the Code Civil and the BGB (March 17, 2012). Indiana University Robert H. McKinney School of Law Research Paper No. 2012-08. URL: SSRN: http:// ssrn.com/abstract=2025265 orhttp://dx.doi.org/10.2139/ssrn.2025265.

8. European Union External Action Service. (2015). A look at the EU-Ukraine Association Agreement, published on 27 April 2015 on the service's homepage. URL: http://eeas.europa.eu/top_ stories/2012/140912_ukraine_en.htm.

9. Hesselink, Martijn W., Cartwright, John. (2008). Precontractual Liability in European Private Law (ed. Hesselink, Martijn W.; Cartwright, John), Cambridge University Press 2008. URL: http:// works.bepress.com/martijn_hesselink/20.

10. Hoffmann, Thomas. (2014). The Weber/Putz "Proportionality Principle: Determining Subsequent Performance Anew? Croatian Yearbook of European Law E E Policy, 10, p. 383-394.

11. Kieninger, Eva-Maria. (2012). Die Haftung für Nebenpflichtverletzungen, in: Schulte-Nölke/Zoll/Jansen/Schulze (eds.). Der Entwurf für ein optionales europäisches Kaufrecht, Sellier 2012.

12. Luts, V. (2012). General Characteristics of Law of Contracts in Ukraine. Law of Ukraine, 5-6/2012, pp. 97-113. 
13. Macdonald, Elisabth. (2013). Dispatching the dispatch rule? The postal rule, e-mail, revocation and implied terms, 19(2) Web JCLI. URL: http://webjcli.org/article/view/239/337.

14. Petrov, Roman. (2013). Legislative approximation and application and of EU law in Ukraine. Petrov, Roman, Elsuwege, P. van. Legal Approximation of EU Law in the Eastern Neighbourhood of the EU: Towards a Common Regulatory Space? Routledge Press, pp. 173-185.

15. Richardson, Lorna. (2014). The DCFR, anyone? Journal of the Law society of Scotland. URL: http://www.journalonline.co.uk/Magazine/59-1/1013494.aspx.

Хоффман томас, доктор філософії (PhD), доцент, Школа права Талліннського технологічного університету, Естонія, м. Таллінн.

e-mail: thomas.hoffmann@ttu.ee

\section{Європеїзація приватного права в Україні. Порівняльний аналіз у галузі зобов'язального} права

Доля Угоди про асоціацію між Свропейським Союзом і Україною, підписаної у березні-червні 2014 р., демонструє перебіг більи ніж 20-річного процесу зближення СС та України: серія амбітних стрибків на захід, не всі з яких були достатньо сильними, щоб повною мірою відповідати юридичній реалізацї правових реформ $i$, що не мени важливо, - відсутність політичної волі. Багато було написано про плюси і мінуси європеїзацї України, і такі публікації почастішають після того, як ескалація, що триває сьогодні, нарешті припиниться. Проте небагато написано про те, чого вже досягнуто з точки зору юридичної гармонізації, особливо у сфері, мени зачепленою політикою, - сфері зобов'язального права. У иій статті здійснюється порівняння украӥнського законодавства про зобов'язання з європейськими ініціативами гармонізаціи: представлено проект загальної системи відліку (DCFR), мета якого - окреслити галузі права, де можливе подальше зближення.

Ключові слова: європеїзація; приватне право; гармонізація; зобов’язальне право.

Надійшла до редколегії 26.06.2017 р. 